Eastern Illinois University

The Keep

Faculty Research \& Creative Activity

Biological Sciences

January 1988

\title{
Environmental, genotypic, and ploidy effects on endopolyploidization within a genotype of Solanum phureja and its derivatives
}

Henry R. Owen

Eastern Illinois University, hrowen@eiu.edu

R. E. Veilleux

Virginia Polytechnic Institute and State University

D. Levy

Virginia Polytechnic Institute and State University

D. L. Ochs

Virginia Polytechnic Institute and State University

Follow this and additional works at: http://thekeep.eiu.edu/bio_fac

Part of the Biology Commons

\section{Recommended Citation}

Owen, Henry R.; Veilleux, R. E.; Levy, D.; and Ochs, D. L., "Environmental, genotypic, and ploidy effects on endopolyploidization within a genotype of Solanum phureja and its derivatives" (1988). Faculty Research \& Creative Activity. 140.

http://thekeep.eiu.edu/bio_fac/140 


\title{
Environmental, genotypic, and ploidy effects on endopolyploidization within a genotype of Solanum phureja and its derivatives
}

\author{
H. R. OWEN, R. E. VEILLEUX, D. LEVY, AND D. L. OCHS
}

Introduction

Protoplast fusion is a procedure for producing hybrids that cannot be produced through sexual means (Austin et al. 1985, 1986; Hein and Schieder 1986; Helgeson et al. 1986). By this process, somatic cells, rather than germ cells, fuse and generate an entire organism. The union of somatic cells may result in hybrid cells or organisms with mitotic and meiotic irregularities (Sree Ramulu et al. 1986) that may be caused, in part, by the doubling of the chromosome number in the fusion product. Protoplasts derived from diverse monoploid, $(2 \mathrm{n}=\mathrm{x}=12)$ genotypes within a species may, when fused, result in somatic hybrids which exhibit fewer meiotic abnormalities (e.g., multivalent chromosomes during prophase I of meiosis) because the fusion partners in this instance contain the gametic, rather than the somatic, chromosome complement.

Monoploid genotypes may be useful in potato germplasm development for several reasons. Protoplasts isolated from monoploid tissues would be more suited to microbial techniques, because of their hemizygous state, than their diploid counterparts (Maheshwari et al. 1982; Melchers 1972). Protoplast fusion of unrelated monoploid genotypes derived from diplandrous donors would produce a heterozygous diploid that, if fertile, could be used in 4x-2x (unilateral) exual polyploidization to create highly heterozygous, tetraploid progeny. If the unreduced gametes of the diploid parent are produced via first division restitution, the heterozygosity inherent in the diploid parent produced by protoplast fusion would be conserved (Veilleux 1985; Wenzel et al. 1982).

Unfortunately, isolated plant cells and tissues in vitro are subject to mitotic irregularities, including chromosomal rearrangement, mutation, and an uncoupling of DNA replication from cell division, a process known as endopolyploidization (Pijnacker et al. 1986; Puite et al. 1986). Plant regeneration from callus or isolated protoplasts would be simplified by using genetically uniform and stable plant material but this cannot always be maintained, particularly in long term cultures that pass through a callus phase (Karp et al. 1985). Over time, in vitro cultures of differentiated or nonmeristematic tissues may contain cells with a wide range of ploidy levels. Similarly, plants regenerated from these cells and tissues may contain nuclei of several ploidy levels, creating a poly somatic condition. It has been demonstrated that monoploid plants may not be entirely monoploid; some proportion of cells may undergo one or more cycles of endopolyploidization in vivo (Sree Ramulu and Dijkhuis 1986; Uijtewaall987). It is necessary, therefore, to assess the cultural, genotypic, and ploidy influences on the process of endopolyploidization in order to select plant material and conditions conducive to monoploid stability.

Flow-cytometric analysis has been used to analyze structural and nuclear components in plant cell preparations with great accuracy and rapidity (Alexander et al. 1985; Arndt-Jovin and Jovin 1977; Galbraith et al. 1984; de Laat and Blaas 1984; Muirhead and Horan 1984). The objectives of the following study were to determine: (i) if the level of endopolyploidization of a monoploid genotype in vivo differs from that in vitro; (ii) if protoplast isolation selects for a particular ploidy level; (iii) if initial ploidy level limits endopolyploidization; and (iv) if monoploid genotypes, derived from anther culture of a single diploid genotype, differ for their level of endopolyploidization. To address the first three objectives, the level of endopolyploidization between in vivo, in vitro, and protoplastderived nuclei from plant material of three ploidy levels were compared. The last objective was addressed utilizing nine monoploid genotypes, all derived from anther culture of Solanum phureja genotype PP5, a diploid South American cultivated potato species possessing several traits useful to breeding programs.

\section{Materials and methods}

Origin of plant material 
Monoploid genotypes (AM2, AM3, AM4, AM6, AM7, AM13, AM20, AM21, AM26, AM27) were obtained via anther culture of Solanum phureja, P.I. 225669, genotype PP5 (Veilleux eta!. 1985). Diploid (AM13-2) and tetraploid (AM13-9) calliclones were generated by leaf-disc culture of AM13 according to Wang and Huang (1975). Plantlets regenerated from both anther and callus culture were subcultured onto basal medium (Murashige and Skoog 1962) for rooting. Rooted plantlets were removed from the tubes, planted in moist sand, and placed in a greenhouse under intermittent mist for acclimatization. Once established, they were transplanted into $8-\mathrm{cm}$, then $20-\mathrm{cm}$ plastic pots and allowed to complete at least two tuber cycles prior to reestablishment of in vitro stocks from shoot tips and nodal cuttings. Plants were propagated in vitro according to Haberlach et al (1985) for at least 8 weeks prior to protoplast isolation. The slow growth of the monoploid plants in vitro necessitated a longer than typical culture duration in order to generate sufficient plant material for protoplast isolation. Leaf material from greenhouse plants was collected from young fully expanded leaves approximately 10 weeks after planting of tubers (ambient spring light and temperature).

\section{Protoplast isolation}

All steps in protoplast isolation were conducted under sterile conditions. All media (flotation, conditioning, enzyme, and rinse) were filter-sterilized and prepared according to Haberlach et al. (1985) . Due to the small size of leaves in vitro, both stem and leaf material were removed from three Magenta boxes (Carolina Biological Supply

Co.), cut into single-node sections, and placed in a $15-\mathrm{cm}$ diameter Petri plate containing a single sheet of filter paper (Whatman No. 3) and $30 \mathrm{~mL}$ of flotation medium. Plates were wrapped in parafilm (American Can Co., Greenwich, CT) and foil and incubated at 23 oc for $24 \mathrm{~h}$. The plant material was transferred to 250 - $\mathrm{mL}$ shaker flasks containing $125 \mathrm{~mL}$ of conditioning medium and incubated in the dark for an additional 24 hat $4{ }^{\circ} \mathrm{C}$. The plant material was poured through a sieve to remove the conditioning medium, placed in a $15-\mathrm{cm}$ diameter glass Petri plate, sliced between two scalpels (No. 10) to form a coarse sample (approximately 2-mm sections) and placed in another $250-\mathrm{mL}$ flask containing $50 \mathrm{~mL}$ enzyme medium. The flasks were sealed with parafilm, placed on an oscillating shaker at 40 oscillations/ min, and incubated for $15 \mathrm{~h}$ at 23 oc under fluorescent light. The enzyme and plant material mixture was poured through a 63J.tm filter, transferred to 50-mL Babcock bottles (Kimble Glass), and centrifuged at $500 \mathrm{rpm}$ for $10 \mathrm{~min}$. The band of protoplasts was removed with a Pasteur pipet, dispersed into a Babcock bottle containing rinse medium, and recentrifuged. A $0.25-\mathrm{mL}$ sample of the protoplasts was placed into a microcentrifuge tube containing I mL of chopping buffer (882 mg sodium citrate, $419 \mathrm{mg}$ MOPS, $915 \mathrm{mg} \mathrm{MgCl} 2,0.1 \mathrm{~mL}$ Triton $\mathrm{X}-100 / 250 \mathrm{~mL}$ ) to burst the protoplast membranes prior to RNAase treatment and DNA staining (Sharma et al. 1983).

\section{Preparation of chopped nuclei}

One gram of leaf material (either in vivo or in vitro) was chopped on ice for 3 min with a razor blade in a 6$\mathrm{cm}$ diameter glass Petri plate containing $3 \mathrm{~mL}$ chopping buffer. The mixture was poured through a 300-J.tm filter and then through a 60-J.tm filter to remove debris. One millilitre of the ftltrate was placed in a microcentrifuge tube for RNAase treatment.

\section{RNA removal and DNA staining}

Both protoplast-derived and chopped nuclei were incubated in $0.5 \mathrm{~mL}$ RNAase solution ( $80 \mathrm{mg}$ Sigma $\mathrm{R}$ 5503 ribonuclease- $\mathrm{A}$ in $100 \mathrm{~mL}$ chopping buffer) at $23{ }^{\circ} \mathrm{C}$ for $30 \mathrm{~min}$. A $0.25-\mathrm{mL}$ aliquot of propidium iodide (PI) solution (40 mg PI in $100 \mathrm{~mL}$ chopping buffer) was added to each sample, incubated on ice for at least an additional $30 \mathrm{~min}$ and analyzed within $3 \mathrm{~h}$.

\section{Flow cytometry}

Stained samples were filtered through a 37-J.tm nylon mesh and analyzed with an Epics V, Model 752 laser flow cytometer and cell sorter (Coulter Electronics, Hialeah, FL). Laser excitation was $300 \mathrm{~mW}$ at $488 \mathrm{~nm}$ from a 5 W Innova 90 Argon Laser (Coherent Inc. , Palo Alto, CA). Three parameters were recorded: forward angle light scatter (FALS) and 90 degree light scatter (90LS, 488-nm dichroic filter) for size and 
granularity determinations, and red fluorescence (RFL, 590-nm dichroic, 610-nm long pass filter) for DNA measurements. The Multiparameter Data Aquisition and Display System (MDADS) and Easy 88

microcomputer analysis (Coulter Electronics) were used for data collection and analysis. FALS, 90LS, and RFL were collected as linear integral, log integral, and linear peak, respectively. Histograms of number of nuclei per fluorescence channel contained 256 channels and were gated on FALS and 90LS dual parameter histograms defining the population of interest. The fluorescence signal from PI-stained preparations is proportional to the DNA content of particles (nuclei) passing through the laser beam. Chicken red blood cells and a microsphere standard (Coulter Electronics) were used as calibration standards. Nuclear counts were set at $10000 /$ sample.

Samples of in vivo chopped nuclei, in vitro chopped nuclei, and protoplast-derived nuclei from PP5, AM13, AM13-2, and AM13-9 were prepared and analyzed on the same day. Likewise, a complete set of protoplast-derived nuclei from the nine monoploid genotypes and PP5 were prepared and analyzed on each of 3 days. DNA measurements of protoplast-derived nuclei from the nine monoploid genotypes and PP5 were replicated after 7 and 14 days, using different sets of 8-week-old plants propagated in vitro under similar conditions. The frequency data for nuclei exhibiting the $1 \mathrm{C}, 2 \mathrm{C}$, and $4 \mathrm{C} \mathrm{DNA}$ contents for the nine monoploid genotypes were tested first using a multivariate analysis of variance (MANOVA) with Wilks' statistic (SAS 1985). This test accounts for the correlation among the three variables. A subsequent ANOVA by genotype was performed on the frequency of nuclei exhibiting the 4C DNA content, the peak which contributed most to the multivariate analysis.

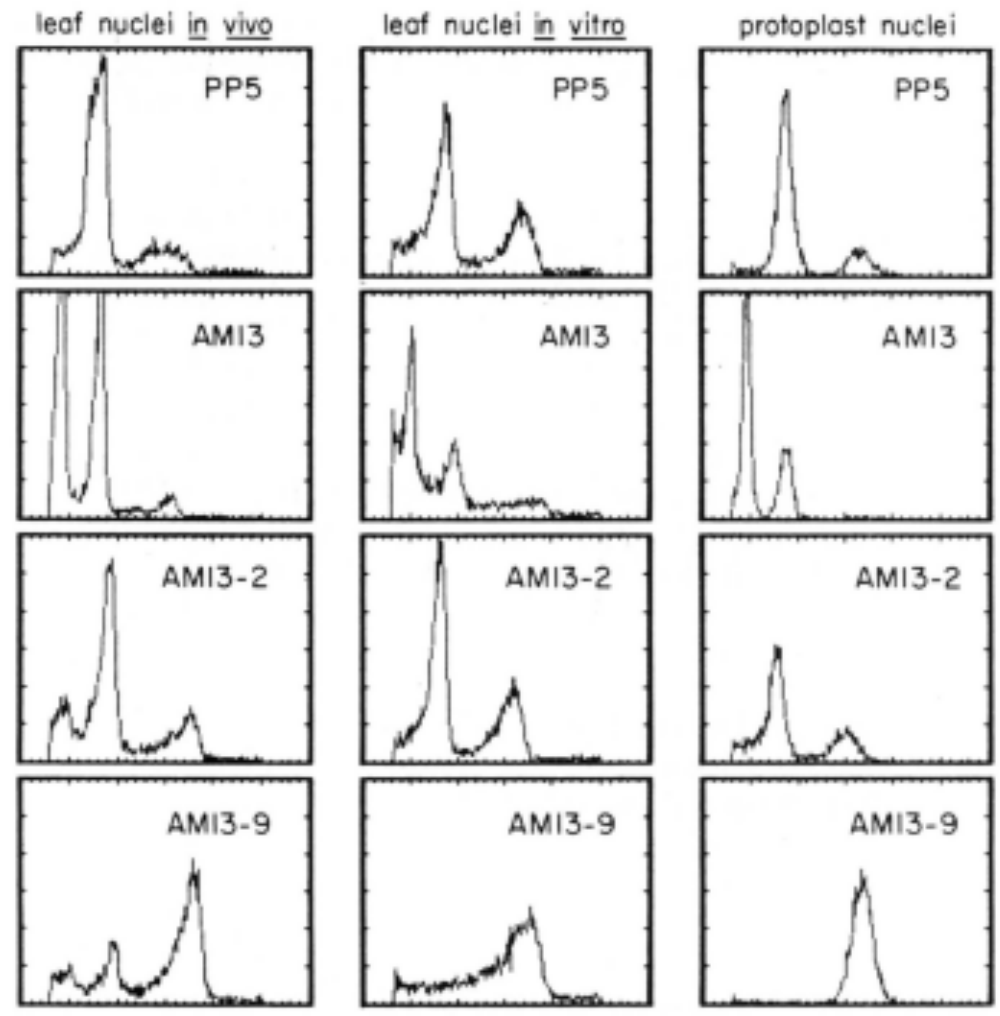

FIG. 1. Flow-cytometric analyses of propidium-iodide stained nuclear DNA of four genotypes of Solanum phureja, PP5 (antherdonor, $2 n=2 x=24$ ), AM13 (anther-derived monoploid, $2 n=x=1$ 12), AM13-2 (doubled monoploid $2 n=2 x=24$ ), and AM13-9 (twice-doubled monoploid, $2 n=4 x=48$ ). Samples were taken from leaf nuclei in vivo, leaf nuclei in vitro, and protoplast nuclei extracted from in vitro plantlets. The $x$-axis represents the channel number (0-256) and the ordinate the frequency of nuclei in each channel (of 10000 counted). 


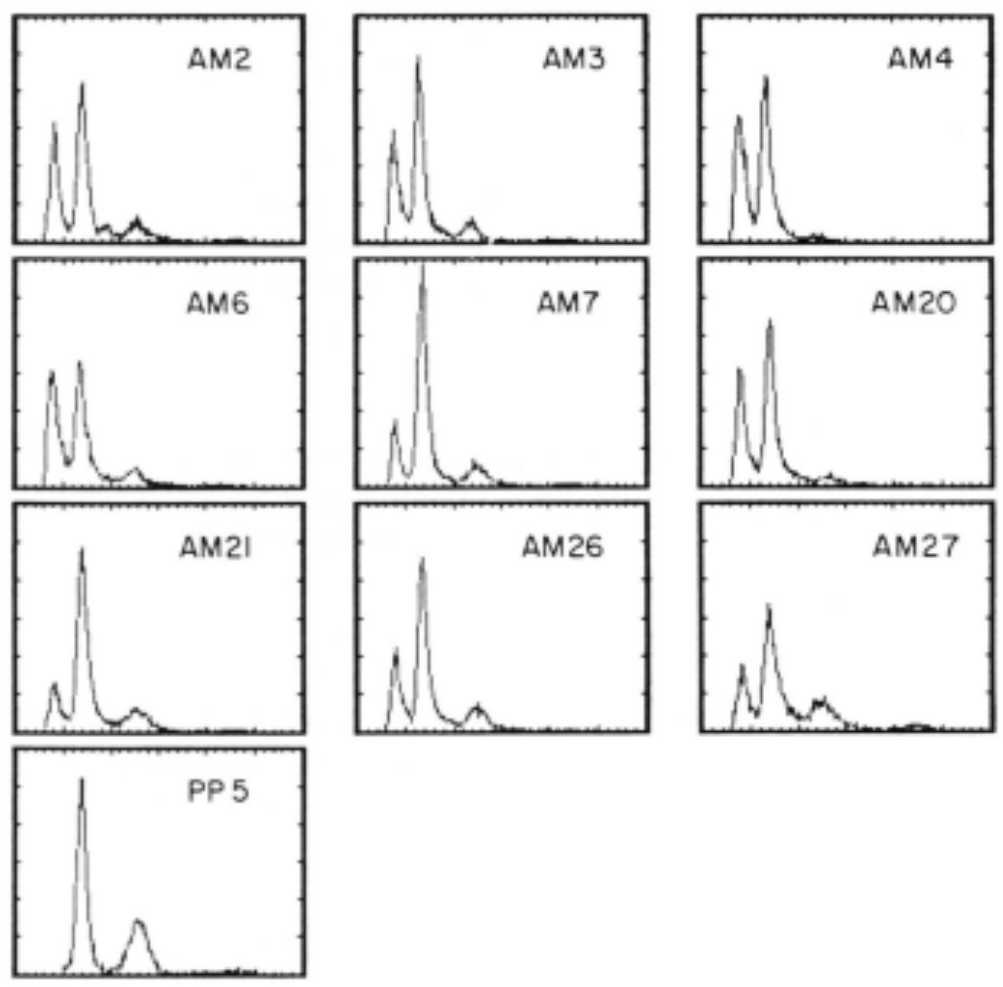

FIG. 2. Flow-cytometric analyses of propidium-iodide stained, protoplast-derived nuclear DNA of nine monoploid $(2 n=x=12)$, anther-derived genotypes (AM2-AM27) and diploid $(2 n=2 x=24)$, anther-donor genotype (PP5) of Solanum phureja. The $x$-axis represents the channel number (0-256) and the $y$-axis the frequency of nuclei (of 10000 counted) in each channel.

\section{Results}

DNA histograms of the anther-donor genotype (PP5) from leaf nuclei both in vivo and in vitro and protoplast-derived nuclei illustrated DNA peaks characteristic of diploid populations (Fig. 1). All three histograms exhibited a large $2 \mathrm{C}$ peak containing approximately $70 \%$ of the nuclei, corresponding to GoG, phase, and a smaller 4C peak, which includes G2 + M phases of the cell cycle. Protoplast-derived nuclei produced cleaner histograms because of the removal of chloroplasts and other cellular components during sample preparation (protoplast flotation and rinsing) and (or) the elimination of fragmented nuclei that may have resulted from sample preparation during chopping.

Histograms of the monoploid, anther-derived genotype (AM13), contained 1C, 2C, and 4C peaks for both in vivo and in vitro chopped nuclei. The second peak included both G2 and M phases, thus it was not possible to discriminate between a single cycle of endoreplication and DNA replication prior to cytokinesis in this peak. However, because the $4 \mathrm{C}$ peak resulted from either $\mathrm{M}$ phase cells of single-cycle endoreplicated cells, or G2 cells that had undergone two cycles of endoreplication, it was clear that endopolyploidization had occurred in the monoploid preparations. The DNA distribution of protoplast-derived nuclei from monoploid genotype AM13 did not contain a 4C peak, so endopolyploidization was not certain in this sample.

Preparations from diploid (AM13-2) and tetraploid (AM13-9) clones in vivo also contained 1C, 2C, and 4C peaks, with the peak of highest frequency corresponding to the ploidy level determined for the clone by examination of chromosomes in Feulgen-stained root tip cells. This suggests that endopolyploidization was not complete within the whole plant in vivo, creating a mixoploid condition. Preparations of leaf nuclei in vitro for both clones did not contain DNA of lower ploidy levels. Because these preparations were from 
plant material reintroduced in vitro from shoot tips or single node cuttings of the in vivo plants, endopolyploidization was either complete within the ex plants, or the conditions of plant growth in vitro favored replication of the cells of higher ploidy levels.

DNA peaks of nuclei from the nine monoploid genotypes (Fig. 2) showed 1C, 2C, and 4C peaks, demonstrating endopolyploidization in protoplast-derived preparations. Chicken red blood cells recorded a peak channel number of 41 that overlapped with the $1 \mathrm{C}$ peak of the monoploid genotypes, thus necessitating its use as an external standard only. Multivariate analysis of variance indicated differences among genotypes for the three DNA peaks $(\mathbf{F}=2.38, \mathrm{p}<0.01$ by Wilks' criterion). Subsequent canonical discriminant analysis indicated that most of the difference was due to variability among genotypes for the $4 \mathrm{C}$ peak. An independent analysis of the $4 \mathrm{C}$ peak indicated genotypic differences for frequency of cells exhibit ing endopolyploidization (Table 1). However, in another separate analysis, variability for frequency of nuclei exhibiting the 1C DNA content was not evident among the monoploid genotypes (Table 1), allowing for analysis of the effect of sampling date (i.e., replication effect) on frequency of 1C DNA content by disregarding genotypes. A significant difference was found among replications $(\mathbf{P}<$ 0.0001 ), with a mean frequency of $1 \mathrm{C}$ nuclei of $42.9,38.9$, and $35.8 \%$ for protoplasts extracted on May 21 , May 28, and June 4, 1987, respectively. A significant negative correlation was found between $1 \mathrm{C}$ and 4C DNA content $(\mathbf{r}=-0.63, \mathbf{P}<0.0005)$. In addition, the frequency of $\mathrm{G}$, phase nuclei exhibiting the $1 \mathrm{C}$ DNA content in the monoploid genotypes was consistently lower (mean $=25.3 \%$ ) than that for $\mathrm{G}$, phase nuclei with the 2C DNA content of the diploid, anther-donor genotype (mean $=61.6 \%)$. Similarly, the frequency of nuclei with the 2C DNA content (G2 phase + single cycle endoreplicated cells at G, phase) from the monoploid genotypes was higher than that of nuclei with the 4C DNA content (again G2 phase + single cycle endoreplicated cell at $\mathrm{G}$, phase) of the diploid, anther-donor genotype $(52.6 \%$ and $31.8 \%$ respectively).

TABLE 1. Means of three replications for fluorescence channel number and percent of protoplast-derived nuclei (of 10000 counted per sample) in 1C, 2C, and 4C DNA peaks for nine monoploid (AM) genotypes and diploid anther-donor genotype PP5

\begin{tabular}{lccccccc}
\hline \hline & \multicolumn{3}{c}{ Mean channel number } & & \multicolumn{3}{c}{ \% of nuclei \pm sd } \\
\cline { 2 - 4 } \cline { 6 - 8 } Clone & $1 \mathrm{C}$ & $2 \mathrm{C}$ & $4 \mathrm{C}$ & & $1 \mathrm{C}$ & $2 \mathrm{C}$ & $4 \mathrm{C}$ \\
\hline AM2 & 41 & 73 & 130 & & $39.9 \pm 9.9$ & $44.4 \pm 7.4$ & $8.2 \pm 2.5 \mathrm{bc}$ \\
AM3 & 38 & 68 & 126 & & $25.1 \pm 8.1$ & $53.5 \pm 2.0$ & $12.9 \pm 3.7 a b c$ \\
AM4 & 39 & 68 & 126 & & $31.5 \pm 12.0$ & $59.0 \pm 10.1$ & $5.0 \pm 2.6 c$ \\
AM6 & 39 & 69 & 130 & & $27.3 \pm 11.1$ & $49.8 \pm 5.1$ & $13.4 \pm 4.2 a b c$ \\
AM7 & 39 & 69 & 128 & & $22.8 \pm 7.8$ & $56.7 \pm 12.9$ & $14.7 \pm 3.0 a b$ \\
AM20 & 37 & 68 & 127 & & $23.4 \pm 9.0$ & $51.5 \pm 7.2$ & $8.8 \pm 3.3 b c$ \\
AM21 & 40 & 69 & 128 & & $19.2 \pm 3.5$ & $61.5 \pm 8.4$ & $14.4 \pm 5.0 a b$ \\
AM26 & 43 & 73 & 137 & & $15.8 \pm 11.0$ & $50.4 \pm 6.7$ & $18.8 \pm 7.0 a$ \\
AM27 & 39 & 70 & 130 & & $22.6 \pm 7.1$ & $46.4 \pm 1.0$ & $19.7 \pm 0.7 a$ \\
PP5 & & 70 & 130 & & $61.6 \pm 0.7$ & $31.8 \pm 1.6$ \\
\hline
\end{tabular}

NotE: Letters within the $4 \mathrm{C}$ column indicate mean separation by the Student-Newman-Keuls' test at the $5 \%$ level, $N=3$.

\section{Discussion}

As cells and tissues become more differentiated and removed from meristematic zones or growth stages, DNA synthesis and cytokinesis become less synchronous (Pijnacker et al. 1986). For plant cell isolation, manipulation, and regeneration to be useful in germ plasm improvement, genetic and genomic stability should be predictable. Current methods for cell and tissue culture, and for genetic manipulation, require the transfer of plant cells from their natural environments to synthetic ones. The response of plant cells to new environments may depend upon internal genetic factors and external cultural factors. The present study demonstrated that both of these factors may affect the process of endopolyploidization. 
Nuclei from monoploid protoplast preparations exhibited a range of C values. Sree Ramulu and Dijkhuis (1986) also noted this occurrence in monoploid S. tuberosum genotypes and demonstrated variability among tissues for the degree of endopolyploidization. Protoplast preparations from monoploid leaf tissue only, or a combination of leaf and stem tissue, did not differ in their array of DNA values in our investigations.

Genotypes AM13, AM13-2, and AM13-9 differ in ploidy but, except for the possibility of somaclonal variation induced during the culture process, are genetically similar. Thus, they are especially useful for separating ploidy influences from genotypic effects. DNA histograms from the diploid (AM13-2) and tetraploid (AM13-9) clones did not contain C values indicative of endopolyploidization (i.e., 8C or 16C, respectively), as did the monoploid genotype from which they were derived (AM13). Thus, a limit to endopolyploidization caused by factors other than genotype has been indicated. This limit to endopolyploidization was further supported by the absence of an $8 \mathrm{C}$ peak in tetraploid preparations from all three environments (in vivo, in vitro, and protoplast-derived nuclei) and from protoplast preparations of nine monoploid genotypes. The monoploid data suggested that genotype may influence the susceptibility of a cell to undergo endopolyploidization, but that other factors impose limits to this process.

Regarding cell cycle phase, $1 \mathrm{C}$ nuclei from monoploid preparations correspond to $2 \mathrm{C}$ nuclei from diploid preparations (both representing G0G, phase); similarly, 2C nuclei from monoploid cells correspond to 4C nuclei of diploid cells (both representing G2 + M). However, the $1 \mathrm{C}$ monoploid frequencies were consistently lower than the $2 \mathrm{C}$ diploid frequency, and the $2 \mathrm{C}$ monoploid frequencies were consistently higher than the 4C diploid frequency, suggesting more endopolyploidization in monoploid preparations. Variability among the monoploid genotypes for frequency of $4 \mathrm{C}$ nuclei indicated that the degree of endopolyploidization was influenced by genotype. When selecting monoploid genotypes for cell fusion, it may be useful, therefore, to determine the fraction of $4 \mathrm{C}$ cells in a sample, since it is the first clear indication of endopolyploidization and a better predictor of a genotype's susceptibility to undergo endopolyploidization during subsequent cell culture and plant regeneration. The negative correlation between 1C and 4C DNA content of the monoploid genotypes suggests that analysis and sorting for higher monoploid status may also select for genotypes having a higher monoploid stability. If monoploid stability in organized tissue is indicative of ploidy stability during cell and tissue culture, selection of monoploid fusion partners that retain a high frequency of $1 \mathrm{C}$ nuclei may produce a higher occurrence of diploid heterokaryons after somatic hybridization and may reduce the frequency of polyploidy regenerants from callus.

\section{Acknowledgements}

The authors wish to thankS . M. Piovano for help in sample preparation, R. H. Pyle for assistance in flowcytometric analyses, and Dr. Eric Smith for statistical consultation. Additional support was provided by the Jeffress Memorial Trust (J-77) and the U.S. Department of Agriculture Competitive Research Grants office (85-CRCR-1-1813).

ALEXANDER, R. G., CocKING, E. C. , JACKSON, P. J. , and lETT, J. H. 1985. The characterization and isolation of plant heterokaryons by flow cytometry. Protoplasma, 128: 52-58.

ARNDT-JOVIN , D. J., and JoviN, T. M. 1977. Analysis and sorting of living cells according to deoxyribonucleic acid content. J. Ristochern. Cytochem. 25: 585-589.

AUSTIN, S., BAER, M. A., and HELGESON, J. P. 1985 . Transfer of resistance to potato leaf roll virus from Solanum brevidens into Solanum tuberosum by somatic fusion. Plant Sci. 39: 75-82.

AUSTIN, S., EHLENFELDT, M. K. , BAER, M.A., and HELGESON, J. P. 1986. Somatic hybrids produced by protoplast fu sion between $\mathrm{S}$. tuberosum and S. brevidens: phenotypic variation under field conditions. Theor. Appl. Genet. 71: 682-690.

DELAAT, A. M. M., and BLAAS, J. 1984. Flow-cytometric characterization and sorting of plant 
chromosomes. Theor. Appl. Genet. 67: 463-467.

GALBRAITH, D. W., AFONSO, C. L., and HARKINS, K. R. 1984. Flow sorting and culture of protoplasts-conditions for high frequency recovery, growth and morphogenesis from sorted protoplasts of suspension cultures of Nicotiana. Plant Cell Rep. 3: 151-155.

HABERLACH, G. T., REICHERT, N. A., BAER, M. A., TOWILL, L. E., and HELGESON , J. P. 1985. Isolation, culture, and regeneration of protoplasts from potato and several related Solanum species. Plant Sci. 39: 67-74.

HEIN, T., and SCHIEDER, 0. 1986. An improved method of mechanically isolated heterokaryons of potato. Z. Pflanzenzuecht. 97: 255-260.

HELGESON, J. P., HUNT, G. J., HABERLACH, G. T., and AUSTIN, S. 1986. Somatic hybrids between Solanum brevidens and Solanum tuberosum: expression of a late blight resistance gene and potato leaf roll resistance. Plant Cell Rep. 3: 212-214.

KARP, A., RISIOTT, R., JoNES , M.G. K. , and BRIGHT, S. W. J. 1985 . Chromosome doubling in monohaploid and dihaploid potatoes by regeneration from cultured leaf explants. Plant Cell Tissue Organ Cult. 3: 363-373.

MAHESHWARI, S. C. , RASHID, A., and TYAGI , A. K. 1982. Haploids from pollen grains-retrospect and prospect. Am. J. Bot. 69: 865-879.

MELCHERS, G. 1972. Haploid higher plants for plant breeding. Z. Pflanzenphysiol. 67: 19-32.

MUIRHEAD, K. A. , and HORAN , P. K. 1984. Applications of flow cytometry to tissue culture systems . Adv. Cell Cult. 3: 57-91.

MURASHIGE, T., and SKOOG, F. 1962. A revised medium for rapid growth and bioassays with tobacco tissue cultures. Physiol. Plant. 15: 473-497.

PIJNACKER, L. P., HERMELINK, J. H. M., and FERWERDA, M. A. 1986. Variability of DNA content and karyotype in cell cultures of an interdihaploid Solanum tuberosum. Plant Cell Rep. 5: 43-46.

PUITE, K. J. , RoEST, S., and PIJNACKER, L. P. 1986. Somatic hybrid potato plants after electrofusion of diploid Solanum tuberosum and Solanum phureja. Plant Cell Rep . 5: 262-265.

SAS INSTITUTE INC. 1985. SAS user's guide: statistics. SAS Institute Inc., Cary, NC.

SHARMA, D. P., FIROOZABADY, E., AYRES, N. M. , and GALBRAITH , D. W. 1983. Improvement of anther culture in Nicotiana: media, cultural conditions and flow cytometric determination of ploidy levels. Z. Pflanzenphysiol. $111: 441-451$.

SREE RAMULU, K., and DuKHUIS, P. 1986. Flow cytometric analysis of polysomaty and in vitro genetic instability in potato. Plant Cell Rep. 5: 234-237.

SREE RAMULU, K. , DIJKHUIS, P., ROEST, S. , BOKELMANN, G. S., and DEGROOT, B. 1986. Variation in phenotype and chromosome number of plants regenerated from protoplasts of dihaploid and tetraploid potato. Plant Breeding, 97: 119-128.

UIJTEWAAL, B. A. 1987. Ploidy variability in greenhouse cultured and in vitro propagated potato Solanum phureja monoploids $(2 \mathrm{n}=\mathrm{x}=12)$ as determined by flow cytometry . Plant Cell Rep. 6 : 252-255.

VEILLEUX, R. 1985. Diploid and polyploid gametes in crop plants: mechanisms of formation and 
utilization in plant breeding. Plant Breed . Rev. 3: 253-288.

VEILLEUX, R. E., BoozE-DANIELS, J., and PEHU, E. 1985 . Anther culture of a 2n pollen producing clone of Solanum phureja Juz. \& Buk. Can. J. Genet. Cytol. 27: 559-564.

WANG, P. J. , and HUANG, L. C. 1975. Callus cultures from potato tissues and the exclusion of potato virus x from plants regenerated from stem tips. Can. J. Bot. 53: 2565-2567.

WENZEL, G., MEYER, C. , PRZEWOZNY, T., UHRIG, H. , and SCHIEDER, 0 . 1982. Incorporation of microspore and protoplast techniques into potato breeding programs. In Variability in plants regenerated from tissue culture. Edited by E. D. Earle and Y. Demarly . Praeger Scientific, New York. pp. 290-302. 